\title{
Assessment of Maize Yield Loss to Determine Economic Injury Levels (Eils) Due To the Infestation by Stem Borers with Insecticidal Control under the Egyptian Conditions
}

\author{
Massoud, A.Magdy ${ }^{1}$, Zaghloul, A.Osman ${ }^{1}$, Barakat, S.Ahmed ${ }^{2}$, Ebieda.M.Ahmed ${ }^{3}$, Amr A.Abou-gleel ${ }^{2}$
}

\section{ABSTRACT}

This investigation was conducted in two subsequent (2014 and 2015) summer seasons, for the purpose of appraising grain yield losses to corn plants (Zea mays $\mathbf{L}$.), due to attack by the lepidopteran stem borers, Sesamia cretica Led. (Noctuidae), Ostrinia nubilalis (Hb.) (Pyraustidae) and Chilo agamemnon (Bles.) (Crambidae).

Maize plants were treated with the recommended doses of five insecticides:- Chloropyriphose (Pyreban ${ }^{\circledR}$ $48 \%$ ), the novel insecticide Spintoram (Radiant ${ }^{\circledR} 12 \% \mathrm{SC}$ ), Indoxacarb (Avaunt $^{\circledR} \quad 15 \%$ EC), Chlorantranliprole (Coragen $^{\circledR} 20 \%$ SC) and the natural biological agent Azadirachtin (Achook ${ }^{\circledR}$ 0.15 EC). Obtained data revealed that loss percentages were $0.00,11.23,24.60,28.34,39.04$ and 39.25 for Cholorotraniliprol, Indoxacarb, Spintoram, Chloropyrephose, Azadirachtin and control, respectively in 2014.

In 2015 the corresponding percentages were as follows: Azadirachtin (36.57), Chloropyrephose (30.69) Spintoram (9.97), Indoxacarb (1.10) and $53.62 \%$ for the control.

As a general observation, the larval number of each species increased maize grain yield loss. Loss percentages are a prerequisite step for the determination of the economic injury level for each borer, according to the procedure indicated by Pedigo and Higley (1996). Econmice injury levels (EILs) due to infestation with $S$. cretica were (1.51) for Cholorotraniliprol, (0.93) Indoxacarb, (1.75) Spintoram, (0.83) Chloropyrephose, and (1.31) for Azadirachtin

These levels due to infestation by $O$. nubilalis were $2.42,1.57,2.68,1.38$ and 1.75 ; while they were $0.60,0.39$, 0.66, 0.31 and 0.32 due to infestation with $C$. Agamemnon when treated with the forementioned insecticides respectively, in 2014. In season 2015 the corresponding respective EILs values were 2.08, 1.40, 2.25, 1.26 and 1.87 for Chlorotraniliprol, Indoxacarb, Spintoram, Chloropyrephose and Azadirachtin, respectively, for $S$. cretica ; 1.00, $0.69,1.48,0.85$ and 0.70 for $C$. agamemnon and $2.33,1.60,3.13,1.57$ and 1.75 for $O$. nubilalis as represented by number of larvae / 10 plant.

Keywords:-Maize stem borers - Insecticidal controlYield loss assessment - Economic injury levels

\section{INTRODUCTION}

Maize (Zea mays L.), is a major cereal crop in Egypt. About 750000 hectares were cultivated with maize in 2012 (FAO, 2012). Maize occupies a crucial economic importance since it is used for human and livestock's consumption and as a source of industrial raw material for the production of bio products such as oil, alcohol and starch.

In Egypt, maize plants are subjecte to infestation with a varity of insect pests. Most important of which is the lepidopteran stem borers, Sesamia cretica Led. (Noctuidae), Ostrinia nubilalis (Hb.) (Pyraustidae) and Chilo agamemnon (Bles.) (Crambidae), that attack the maize plants throughtout the different stages of their growth causing the characteristic symptoms of dead hearts, elongate tunnels and circular holes., respectively, which subsequently affect the grain yield. (Berry and Campbell., 1978; Edwards et al., 1992. Mesbah et al., 2002; Sabbour, 2002 and Idraw and Al-Jouri, 2007).

Attention should be paid for assessing yield loss due to these stem borers because yield loss is a prerequisite step for the determination of economic injury levels (EILs) that represent a salient tool for a decision making program and /or for initiating integrated pest management (IPM) programs in maize field.

As mentioned by Stern et al., (1959) (EIL) is defined as: "the lowest population density of a pest that will cause economic damage; or the amount of pest injury which will justify the cost of control."

Therefore, the current investigation aims at the evaluation of some insecticides against the three stem borers under field conditions and assesses grain yield loss and determine the (EILs) for each of the abovementioned maize borers.

\section{MATERIALS AND METHODS}

\section{1- Experimental site and design}

Field trials were conducted by cultivating the maize hybrid (SC 10) during the two successive summer seasons of 2014 and 2015 at the Research Experimental Farm of the Faculty of Agriculture, Saba Bacha , Alexandria University, situated at the $10^{\text {th }}$ village,

\footnotetext{
${ }^{1}$ Plant Protection Department Faculty of Agriculture

(Saba-Basha) - Alexandria University - Egypt

${ }^{2}$ Plant Protection Institute - Agriculture Research Centre - Egypt

${ }^{3}$ Suger crops Institute - Agriculture Research Centre - Egypt

Received November 27, 2016, Accepted December 25, 2016
} 
Abees, Alexandria, Egypt. An experimental area was divided into plots, each of which was $12 \mathrm{~m}^{2}(3 \times 4 \mathrm{~m})$. The plants were grown along a distance of $30 \mathrm{~cm}$ apart and of $70 \mathrm{~cm}$. between rows. All experimental plots received the recommended agricultural practices.

\section{2- Insecticide treatments}

\section{Used chemicals}

Two groups of insecticides were used; namely, Chloropyriphose (Pyreban ${ }^{\circledR} 48 \%$ ), as well as the novel insecticides Spintoram (Radiant ${ }^{\circledR} 12 \% \mathrm{SC}$ ), Indoxacarb (Avaunt $^{\circledR}$ 15\% EC), Chlorantranliprole (Coragen ${ }^{\circledR} 20 \%$ $\mathrm{SC}$ ) in addition to the natural biological agent Azadirachtin $\left(\right.$ Achook $\left.^{\circledR} 0.15 \mathrm{EC}\right)$.

Maize plants were treated with insecticides twice, after 25 and 45 days from sowing which took place on the first week of the June in both seasons for the control of the three concerned stem borers. Treatments were arranged in a complete randomized block design (CRBD) with 3 replicates for each treatment plus other 3 replicates without any treatment as check (control).To create a range of stem borer population densities and crop damage, larval numbers before and after each insecticidal application were recorded.

\section{Reduction percentage calculation}

The control efficacy of the chemicals was estimated as percentages of infestation reduction calculated according to the equation of Henderson and Tilton (1955):

Reduction \% $=[1-(\mathrm{A} / \mathrm{B} \times \mathrm{C} / \mathrm{D}) \quad \mathrm{x} 100]$,

Where:-

$\mathrm{A}=$ Mean no. of larvae in treatment after spraying, $\mathrm{B}=$ Mean no. of larvae in treatment before spraying, $\mathrm{C}=$ Mean no. of larvae in untreated check (control) before spraying and $\mathrm{D}=$ Mean no. of larvae in check after spraying.

At harvest all maize ears of each plot were collected, weighed and adjusted to find out the yield per feddan expressed as (ardab/feddan). (One ardab is equal to 150 $\mathrm{kg})$.

\section{3- Maize grain yield loss assessment}

Once again, different insecticides at recommended doses were used for the purpose of creating gradient levels of infestation. Hence it was possible to study the relationship between the mean number of each stem borer larvae and mean percentage of loss. Appraisal of maize grain loss percentages was calculated according to the following formula modified for the formula described by Zahid et al., (2008):

$\%$ loss percent $=\left[\left(\mathrm{Y}_{o p}-\mathrm{Y}_{t 2 \ldots 5} / \mathrm{Y}_{o p}\right) \quad \mathrm{x} 100\right]$,

Where :-
$\mathrm{Y}_{o p}=$ optimal yield, which is corresponding to $\mathrm{T}_{1}$ where the maize plants were sprayed with Chlorantranliprole.

$\mathrm{Y}_{t 2 \ldots 5}=$ yield for each insecticidal treatment

\section{4- Determination of the multiple economic injury} levels of the stem borer complex

The following steps, in order, represent the approach to determine EIL for each key insect pest of the stem borers:

a. Regression of insect population three considered on yield loss.

b. calculating the values of (EILs) by applying the following formula:

$\mathrm{EIL}=\mathrm{C} / \mathrm{VIDK}$

Where:

$\mathrm{C}=$ the management cost per production unit (e.g., L.E./fed.).

$\mathrm{V}=$ market value per production unit (e.g., L.E. $/ \mathrm{kg}$ ).

$\mathrm{I}=$ injury unit per pest equivalent.

$\mathrm{D}=$ damage per unit injury (e.g., $\mathrm{kg}$ reduction/fed./ injury unit).

$\mathrm{K}=$ proportional reduction in injury due to management.

For both 2014 and 2015 seasons the management costs were estimated by calculating costs of insecticide, sprayers and labour. Such data were obtained from the department of Plant Protection, Ministry of Agriculture operation and farmers' inquiry. The price of yield unit (ardab/ fed.) was estimated as 300L.E/ardab according to the information provided by the Department of Economics and Statistics Ministry of Agriculture. Since, "I $\times \mathrm{D}$ " is equivalent to the " $\mathrm{b}$ " index, i.e, the slope of the regression line $\mathrm{y}=\mathrm{a}+\mathrm{bx}$ formula (Pedigo et al., 1986) the equation and regression relation between the number of larvae/ plant and damage to grain yield were estimated and considered as $D \times I=D^{\prime}$ e.g. and the amount of yield loss was obtained from the slope of the regression equations (Peterson, 1996 and Warabieda, 2015).

The correlation coefficient ' $r$ ' among the variables, hence population level of the pest and reduction in grain yield per plant were worked out using the following formula:

$$
r=\frac{N \sum X Y-\sum X \sum Y}{\sqrt{\left(N \sum X^{2}-\left(\sum X\right)^{2}\right)\left(N \sum Y^{2}-\left(\sum Y\right)^{2}\right)}}
$$

Where:

$r=$ correlation coefficient between variables.

$\mathrm{N}=$ total number of observations 
$\mathrm{X}=$ population levels of larvae/plant

$\mathrm{Y}=$ reduction in grain yield.

All statistical calculations were made by the computer program CO-STAT

\section{RESULTS AND DISCUSSION}

A. Mean grain yield loss assessment

\section{A. 1. (2014) season:}

The mean numbers of $S$. cretica larvae $/ 10$ plants were $3.00,4.00,5.00,6.00$. 11.00 and 11.25 after treatments with Cholorotraniliprol, Indoxacarb, Spintoram, Chloropyrephose, Azadirachtin and control respectively. The corresponding mean numbers of $\mathrm{O}$. nubilalis larvae/10 plants were 3.65, 5.37, 9.00, 12.33, 16 and $17 / 10$ plants while for, the $C$. agamemnon were $0.89,1.03,2.68,3.32,3.41$ and 4.00 (Table1).

The mean grain weigh $/ 10$ plants were adjusted as the number of plants / feddan were about 24000 and expressed as mean grain yield / feddan. Thes values were 29.92, 26.56, 22.56, 21.44, 18.44 and $18.17 \mathrm{ardab} /$ fed. for the abovementioned insecticides and control, respectively during 2014 season.
Percentages of grain yield loss were appraised estimated by to the previously mentioned formula indicated that the losses were $0.00,11.23,24.60,28.34$, 39.04 and 39.25 for the tested insecticides as well as the control, in respect (Table 1).

Result refer that insecticidal treatments with Cholorotraniliprol and Indoxacarb followed by Spintoram and then Chloropyrephose and Azadirachtin led to subsequent increases in the mean yield of maize grains which have no significant difference between them or the control

\section{A. 2. (2015) season:}

Data in Table (2) indicates that the mean numbers of of $S$. cretica larvae were $4.09,4.55,5.65,7.73,12.53$ and $12.67 / 10$ plants for the treatments $\left(\mathrm{T}_{1}\right)$ Cholorotraniliprol, $\left(\mathrm{T}_{2}\right)$ Indoxacarb, $\left(\mathrm{T}_{3}\right)$ Spintoram, $\left(\mathrm{T}_{4}\right)$ Chloropyrephose, $\left(\mathrm{T}_{5}\right)$ Azadirachtin and control, respectively . As for O. nubilalis, the mean numbers of larvae were $7.91,8.80,11.59,13.35,17.01$ and 18.67 /10 plants, while for $C$. agamemnon the corresponding numbers were $1.68,2.61,4.49,5.35,5.65$ and 6.92 larva /10 plants.

Table 1. Efficacy of 5 tested insecticides (treatments) on larval densities of 3 stem borers and on yield loss in maize field during 2014

\begin{tabular}{|c|c|c|c|c|c|c|}
\hline \multirow{2}{*}{$\begin{array}{l}\text { Insecticide } \\
\text { (treatment) }\end{array}$} & \multicolumn{3}{|c|}{$\begin{array}{c}\text { Mean no. of larvae /10 } \\
\text { plants }\end{array}$} & \multirow{2}{*}{$\begin{array}{c}\text { Mean weight of } \\
\text { Grains }\end{array}$} & \multirow{2}{*}{$\begin{array}{c}\text { Mean weight } \\
\text { of Grains yield } \\
\text { (Ardab/Fed) }\end{array}$} & \multirow{2}{*}{$\begin{array}{c}\% \\
\text { Loss }\end{array}$} \\
\hline & Sc & On & $\mathrm{Ca}$ & & & \\
\hline Cholorotraniliprol $\left(\mathrm{T}_{1}\right)$ & 3.00 & 3.65 & 0.89 & $1.87^{\mathrm{a}}$ & $29.92^{\mathrm{a}}$ & 0.00 \\
\hline Indoxacarb $\left(\mathrm{T}_{2}\right)$ & 4.00 & 5.37 & 1.03 & $1.66^{\mathrm{a} *}$ & $26.56^{\mathrm{a}}$ & 11.23 \\
\hline Spintoram $\left(\mathrm{T}_{3}\right)$ & 5.00 & 9.00 & 2.68 & $1.41^{\mathrm{b}}$ & $22.56^{\mathrm{b}}$ & 24.60 \\
\hline Chloropyrephose $\left(\mathrm{T}_{4}\right)$ & 6.33 & 12.33 & 3.32 & $1.34^{\mathrm{c}}$ & $21.44^{\mathrm{c}}$ & 28.34 \\
\hline Azadirachtin $\left(\mathrm{T}_{5}\right)$ & 11.00 & 16.00 & 3.41 & $1.14^{\mathrm{c}}$ & $18.24^{\mathrm{c}}$ & 39.04 \\
\hline Control (check) & 11.25 & 17.00 & 4.00 & $1.136^{\mathrm{c}}$ & $18.17^{\mathrm{c}}$ & 39.25 \\
\hline
\end{tabular}

* Numbers followed by the same letter(s) in each column are not significantly different.

Sc :- Sesamia cretica led., On:- Ostrinia nubilalis (Hb.) Ca:- Chilo agamemnon (Bles.)

Plant stand was 24000 plants/ feddan

Table 2. Efficacy of 5 tested insecticides (treatments) on larval densities of 3 stem borers and on yield loss in maize field during 2015

\begin{tabular}{|c|c|c|c|c|c|c|}
\hline \multirow{2}{*}{$\begin{array}{l}\text { Insecticide } \\
\text { (treatment) }\end{array}$} & \multicolumn{3}{|c|}{ Mean no. of larvae $/ 10$ plants } & \multirow{2}{*}{$\begin{array}{c}\text { Mean weight of Grains } \\
\text { (kg / } 10 \text { plants/plot) } \\
\text { s/10plant }\end{array}$} & \multirow{2}{*}{$\begin{array}{l}\text { Mean weight of } \\
\text { Grains yield } \\
\text { (Ardab/Fed.) }\end{array}$} & \multirow[b]{2}{*}{$\begin{array}{c}\% \\
\text { Loss } \\
\end{array}$} \\
\hline & Sc & On & $\mathbf{C a}$ & & & \\
\hline Cholorotraniliprol $\left(\mathrm{T}_{1}\right)$ & 4.09 & 7.91 & 1.68 & $1.466^{\mathrm{a} *}$ & $23.46^{\mathrm{a}}$ & 0.00 \\
\hline Indoxacarb $\left(\mathrm{T}_{2}\right)$ & 4.55 & 8.80 & 2.61 & $1.45^{\mathrm{a}}$ & $23.20^{\mathrm{a}}$ & 1.11 \\
\hline Spintoram $\left(\mathrm{T}_{3}\right)$ & 5.65 & 11.59 & 4.49 & $1.32^{\mathrm{a}}$ & $21.12^{\mathrm{a}}$ & 9.97 \\
\hline Chloropyrephose $\left(\mathrm{T}_{4}\right)$ & 7.73 & 13.35 & 5.35 & $1.016^{\mathrm{a}}$ & $16.26^{\mathrm{a}}$ & 30.69 \\
\hline Azadirachtin $\left(\mathrm{T}_{5}\right)$ & 12.53 & 17.01 & 5.65 & $0.93^{\mathrm{a}}$ & $14.88^{\mathrm{a}}$ & 36.57 \\
\hline Control (check) & 12.67 & 18.67 & 6.92 & $0.68^{\mathrm{b}}$ & $10.88^{b}$ & 53.62 \\
\hline
\end{tabular}

* Numbers followed by the same letter(s) in each column are not significantly different.

Sc :- Sesamia cretica led., On:- Ostrinia nubilalis (Hb.) Ca:- Chilo agamemnon (Bles.)

Plant stand was 24000 plants/ feddan 
Mean grain yield / fed. recorded and it was noticed that Cholorotraniliprol $\left(\mathrm{T}_{1}\right)$ was the superior treatment that yielded (23.46) ardab/fed. followed by Indoxacarb (23.20), Spintoram (21.12), Chloropyrephose (16.26) and Azadirachtin (14.88) whereas the control yilded (10.88) ardab/ feddan. Yield loss percents could be arranged in a descending order as follows: Control (53.62), Azadirachtin (36.57), Chloropyrephose (30.69), Spintoram (9.97), Indoxacarb (1.10) and Cholorotraniliprol (0.00).

Previous results infer that the mean weight of maize grains / feddan were higher during the first season than those recorded for the second season. This phenomenon was definitely related to the comparatively low numbers of stem borers larvae that infested maize plants rather than in the first season as well as to the expected differences in environmental factors. Thereby, yield losses in (2014) were relatively lower.

Furthermore, used insecticides acted differently on the larval population of each species. In the sense, that larval numbers as a result of spraying the chemicals indicated reflected differences in the susceptibility of the different species to them. In this regard, it was clear that $C$. agamemnon larvae were the most susceptible to tested insecticides rather than $S$. cretica.

Several authors refered to the deleterious damage of maize borers to maize plants including the works of Jepson, (1954), El- sherif (1965), Hosny and El-saadany (1970); Isa and Awadallah (1975) and Rokaia (2013).

\section{B. Determination of multiple economic injury levels (EILs) of the maize stem borers under syudy:}

\section{B. 1. (2014) season}

Assessment of crop loss is a prerequisite step for the determination of the economic injury level. In that respect the parameter of $\%$ mean loss against the mean number of larvae for each insect pest was essential to get the EILs values (larvae /10 plants).

The total control costs including insecticides price + labour differed for the different used insecticides being L.E 480, 300,440,230 and 240 for Cholorotraniliprol, Indoxacarb, Spintoram, Chloropyrephose and Azadirachtin, respectively (Table 3).

The respective efficacy of control (insect reduction) for S. cretica according to the formula of Henderson $\&$ Tilton (1955) was $0.81,0.81,0.64,0.70$ and 0.46 for the same tested insecticides, respectively.

Regression of yield loss on larval population was calculated by applaying the following formula:-

$\mathrm{Y}=-1.53+1.31 \mathrm{X}$ with $\mathrm{r}^{2}=0.810$
Therefore, the EIL values of $S$. cretica for the different tested chemicals were as follows:

- $($ Cholorotraniliprol $)=480 /(300 * 1.31 * 0.81)=1.51$ larva

- $($ Indoxacarb $)=300 /(300 * 1.31 * 0.81)=0.93$ larva

- $($ Spintoram $)=440 /(300 * 1.31 * 0.64)=1.75$ larva

- $($ Chloropyrephose $)=230 /(300 * 1.31 * 0.70)=0.83$ larva

- $($ Azadirachtin $)=240 /(300 * 1.31 * 0.46)=1.31$ larva

Similarly, the EIL values for O. nubilalis were:

The obtained regression equation was:

$\mathrm{Y}=-1.99+0.881 \mathrm{X}, \mathrm{r}^{2}=0.948$

EIL values were $2.42,1.57,2.68,1.38$ and 1.75 larvae for Cholorotraniliprol, Indoxacarb, Spintoram, Chloropyrephose and Azadirachtin, in succession.

Likewise, for C. agamemnon the obtained regression equation was:

$\mathrm{Y}=-1.80+3.522 \mathrm{X}, \quad \mathrm{r}^{2}=0.898$

EIL values were $0.60,0.39,0.66,0.31$ and 0.32 for Cholorotraniliprol, Indoxacarb, Spintoram, Chloropyrephose and Azadirachtin, in respect, (Table, 3 \& Figs.1,2 and 3).

\section{2. (2015) season}

regression equation for $S$. cretica was:-

$\mathrm{Y}=-3.70+1.07 \mathrm{X}$ with $\mathrm{r}^{2}=0.851$ and

EIL values for the different tested chemicals were 2.08, $1.40,2.25,1.26$ and 1.87 larva for Cholorotraniliprol, Indoxacarb, Spintoram, Chloropyrephose and Azadirachtin, respectively.

For O. nubilalis regression equation was:$\mathrm{Y}=-8.53+1.040 \mathrm{X}$ with $\mathrm{r}^{2}=0.915$

EIL values were 2.33, 1.60, 3.13, 1.57and 1.75 larva for Cholorotraniliprol, Indoxacarb, Spintoram, Chloropyrephose and Azadirachtin, respectively.

For C. agamemnon regression equation was:

$\mathrm{Y}=-4.66+2.11 \mathrm{X}$ with $\mathrm{r}^{2}=0.84$ with EIL values of $1.00,0.69,1.48,0.85$ and 0.70 larva for Cholorotraniliprol, Indoxacarb, Spintoram, Chloropyrephose and Azadirachtin, subsequently (Table, 4 \& Figs.4,5 and 6).

It is worthmentioning that EIL is an important and salient factor in initiating a proper and sound integrated pest management program (IPM) for the studied pests.

The economic injury level is not representing a permanent constant value, but it differs according locality, product price and insecticide cost. In other words it is a dynamic value. 


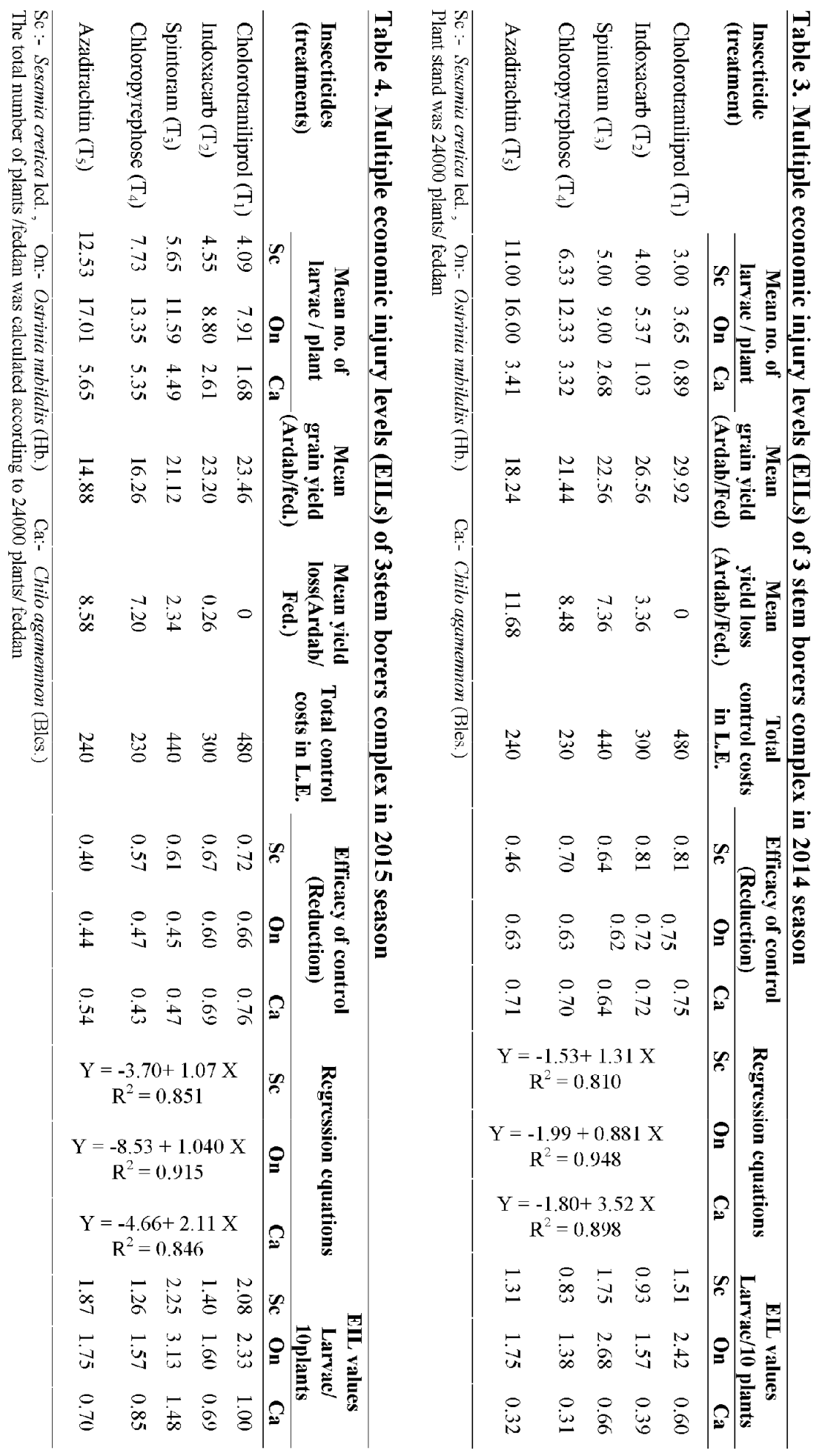




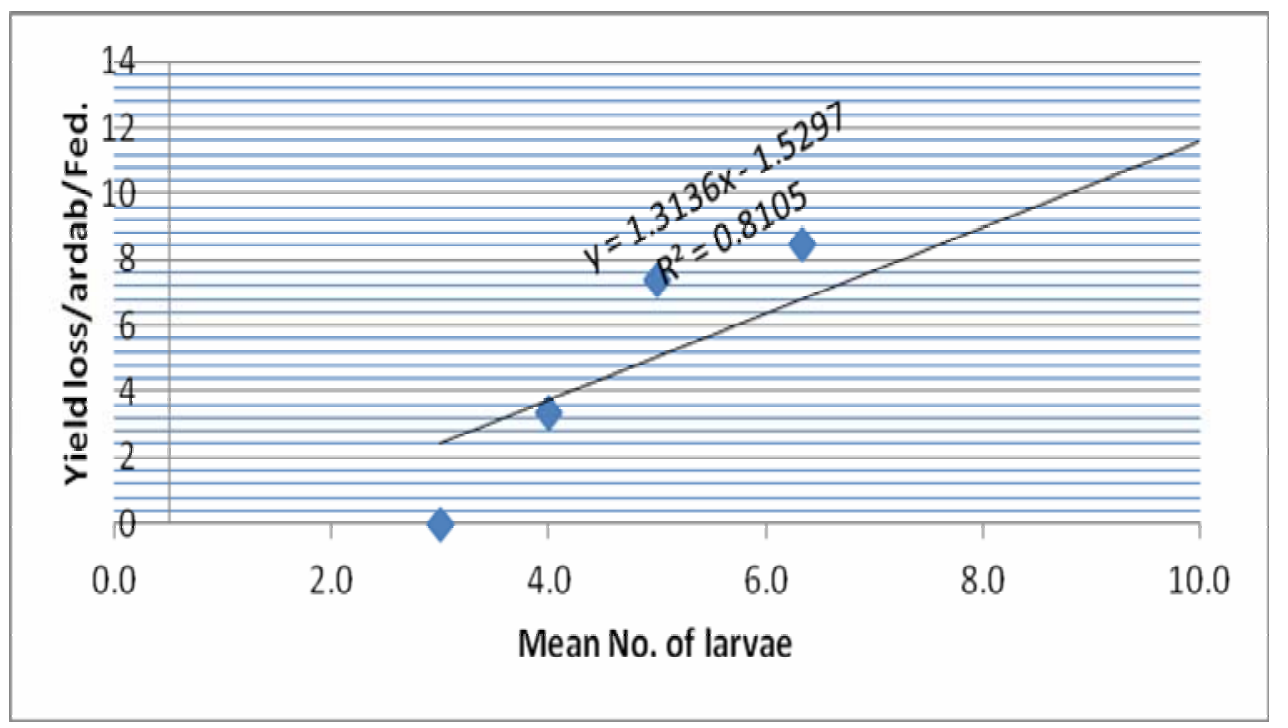

Fig.1. Regression yield loss against mean number of $S$. cretica during 2014 season

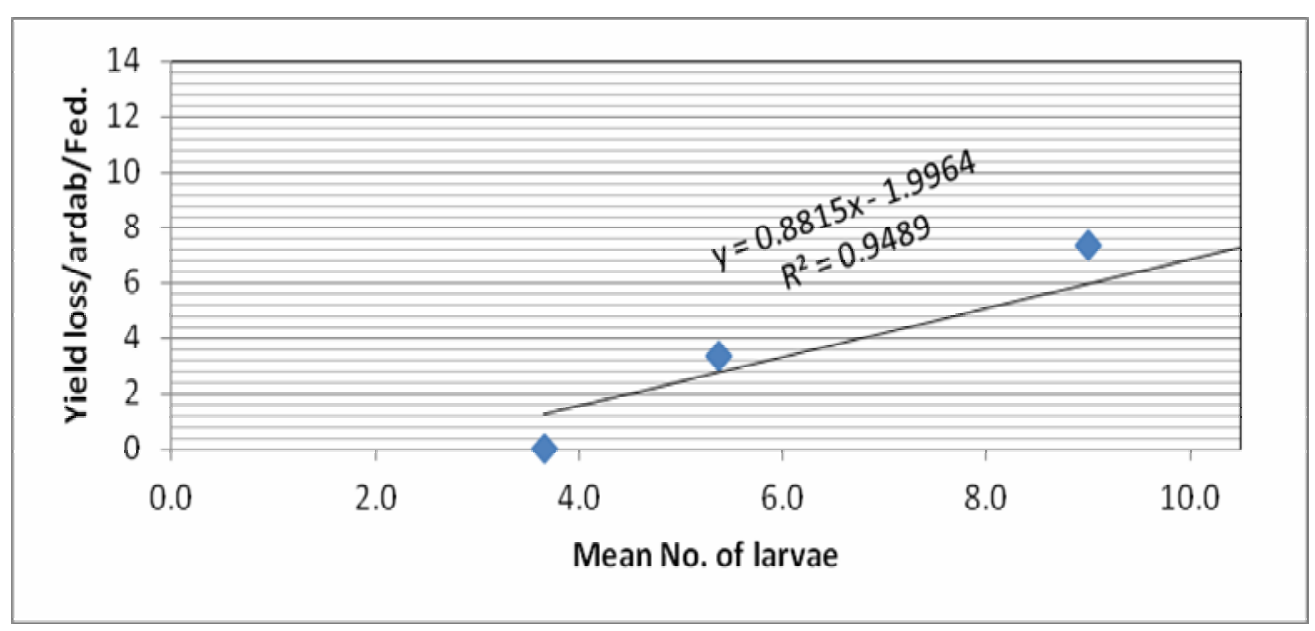

Fig.2. Regression yield loss against mean number of $O$. nubilalis during 2014 season

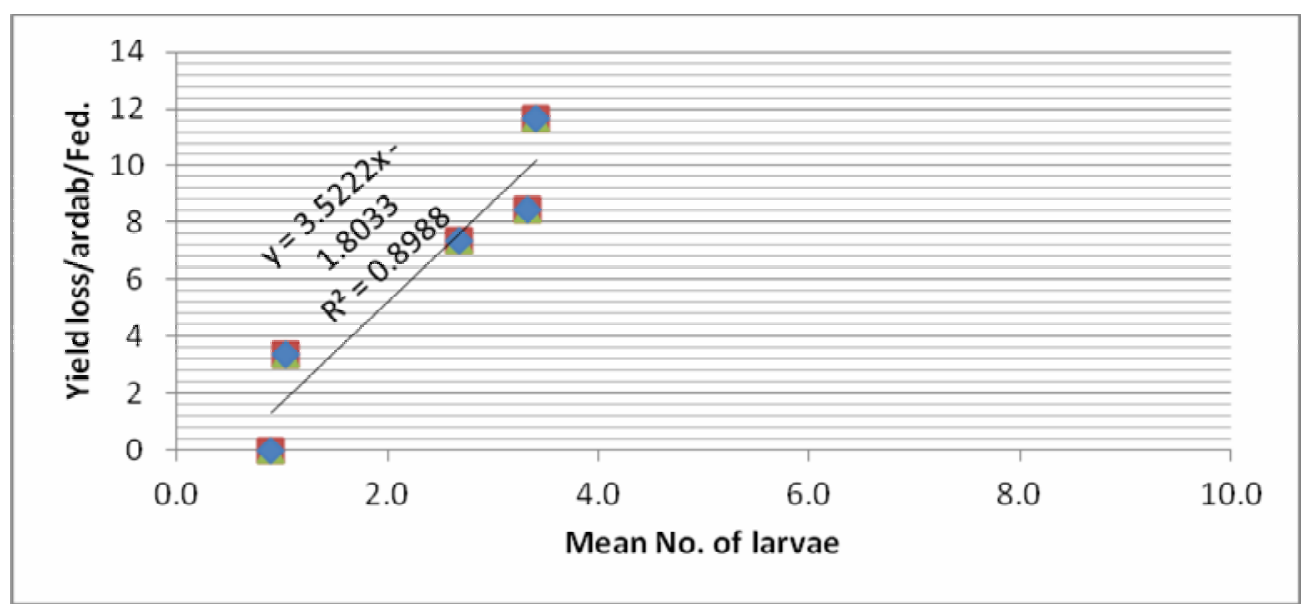

Fig.3. Regression yield loss against mean number of $C$. agamemnon during 2014 season 


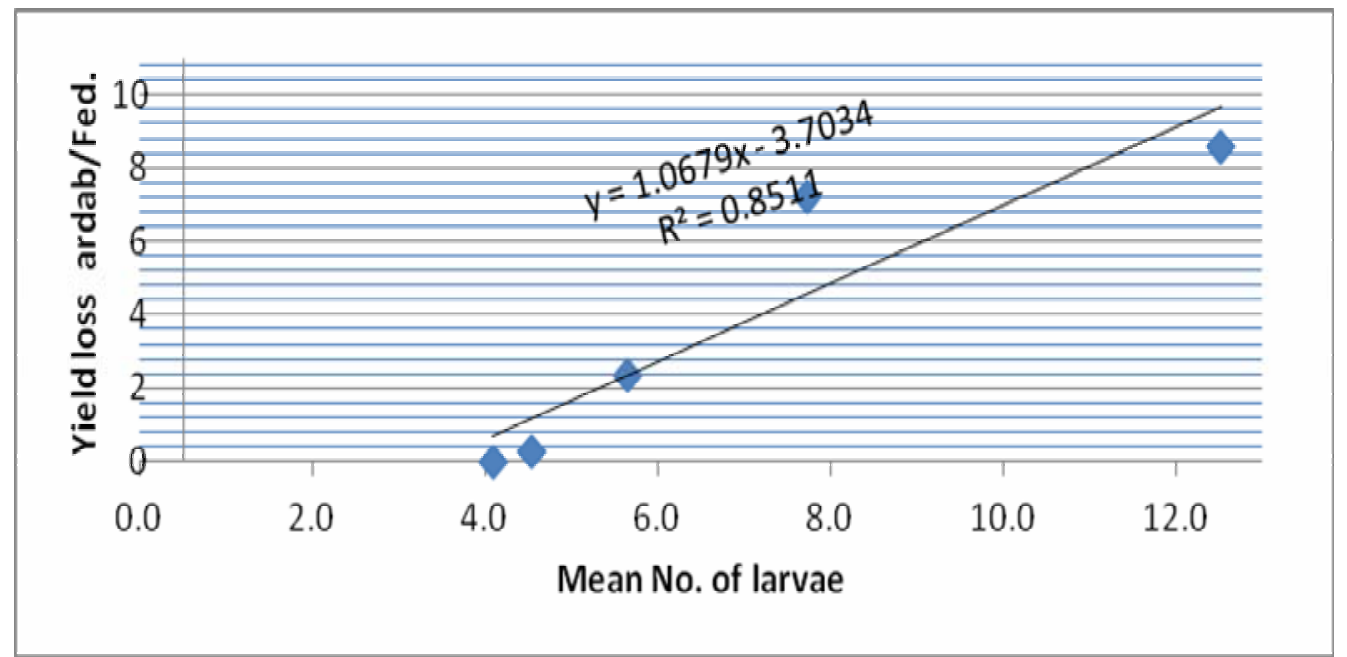

Fig.4. Regression yield loss against mean number of $S$. cretica during 2015 season

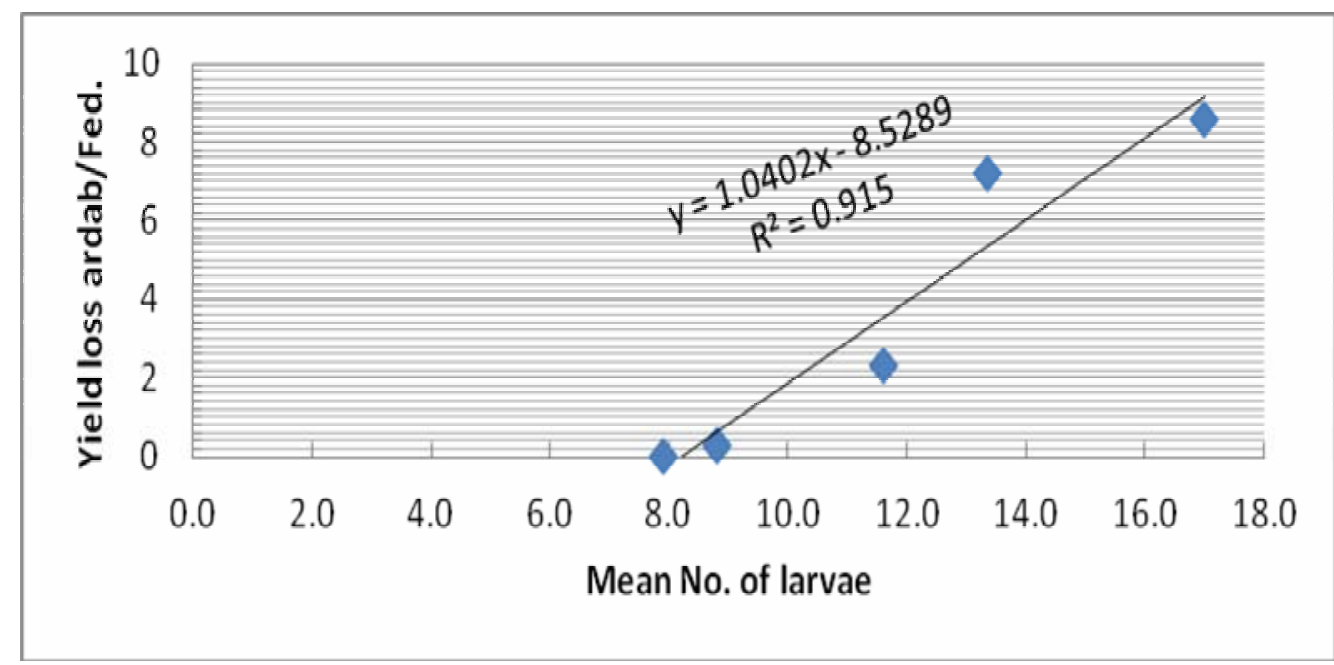

Fig.5. Regression yield loss against mean number of $O$. nubilalis during 2015 season

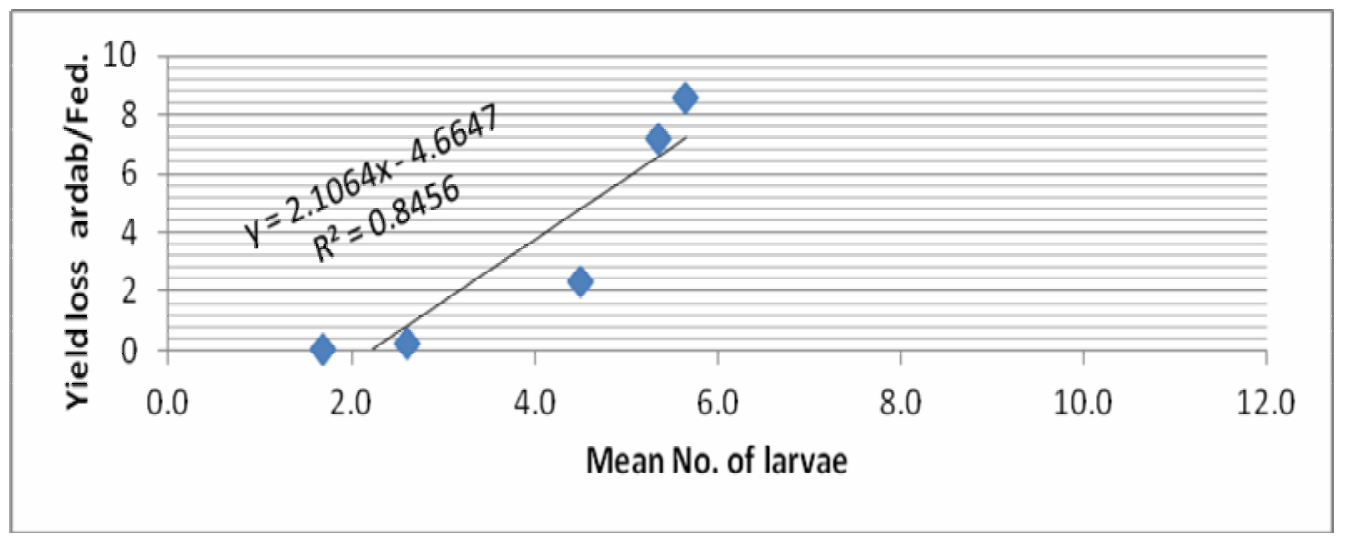

Fig.6. Regression yield loss against mean number of $C$. agamemnon during 2015 season 
Perusing precisely the data included in Tables (3 \&4), it has been noticed that the EILs values varied among the applied insecticides. Such variations might be due to the interaction between chemicals and corn plants, which surely affect the physiological processes and pathways of plants.

The low EIL values in this study validated the recommended schedule of spraying insecticides twice throughout the season as recommended by the Egyptian ministry of Agriculture control officers

\section{REFERENCES}

Berry, E. C. and J. E. Campbell. 1978. European corn borer: relationship between stalk damage and yield losses in inbred and single-cross seed corn, Iowa State J. Res. 53: 49.

Edwards, C. R., J. L. Obermeyer, T. N. Jordan, D. J. Childs, D. H. Scott, J. M. Ferris, R. M. Corrigan and M. K. Bergman. 199. Seed Corn Pest Management Manual for the Midwest, Purdue University CES and Department of Entomology, West Lafayette, IN, 36-124, 183-186.

El-Sherif, S. T. 1965. Studies on the corn borers in Alexandria area, ph.D. Thesis, Fac. Agric. Alexandria Univ. Egypt.

FAO, 2012. http://faostat.fao.org/site/567/default.aspx.

Henderson, C. F. and E. W. Tilton. 1955. Tests with acaricides against the brown wheat mite. J. Econ. Entomol., 48:157-161.

Hosny, M. M. and G. B. Elsaadany. 1970. A brief account on the age of the maize plant at which initial and maximum borer infestation occur. Agric. Res. Rev., 48 (1): 38-42.

Idraw, M. W. and E. Al-Jouri . 2007. Monitoring the effect of some insecticides for corn stem borer control at Deir EzZor region, Syria. Arab Univ.J. Agric.Sci., 15(2): 301312 .

Isa, A. L. and W. H. Awadallah. 1975. Biological studies on corn borers in Egypt I. Seasonal distribution. J. Agric. 53(1): 53-64.
Jepson, W. F. 1954. A critical review of world literature on the lepidopterous stalk to tropical and subtropical grominaceous crop Comm.. Int. Ent. London.

Mesbah, H. A., A. K. Mourad, H. M. El-Nimr, M.A. Massoud and A. A. Abd El-Aziz . 2002. The role of some agricultural practices and fertilizer type on both the incidence of stem borers infestation and corn yield in Egypt. Mededelingen (Rijksuniversiteit te Gent. Fakulteit van de Landbouwkundige en Toegepaste Biologische Wetenschappen) 67 (3): 575-589.

Pedigo, L. P., and L. G. Higley. 1996. Introduction to pest management and thresholds, pp. 3- 9. In Economic thresholds for integrated pest management. University of Nebraska Press, Lincoln, NE.

Pedigo, L. P., S. H. Hutchins and L. G. Higley . 1986. Economic injury levels in theory and practice. Annu. Rev. Entomol. 31: 341-368.

Peterson, R. K. D. 1996. The status of economic-injury-level development, pp. 151- 178. In L.G. Higley and L. P. Pedigo (eds.), Economic thresholds for integrated pest management. University of Nebraska Press, Lincoln, NE.

Rokaia, A. Z. M. 2013. Effect of endomycorhizal fungi in the Integrated pest management of corn stem borers, Ph.D. Thesis, Fac. Agric. Alexandria Univ. Egypt.

Sabbour, M. M. 2002. Evaluation studies of some bio-control agents against corn borers in Egypt. Annals of Agricultural Science (Cairo) 47 (3): 1033-1043.

Stern, V. N., R. F. Smith, R. V. Bosch and K. S. Hagen .1959. The integrated control concept, Hilgarda 29(2): 81101.

Warabieda, W. (2015). Effect of two-spotted spider mite population (Tetranychus urticae Koch) on growth parameters and yield of the summer apple cv. Katja. Hort. Sci. (Prague) 42 (4): 167-175

Zahid, M. A., M. M. Islam, M. H. Reza, M. H. Z. Prodhan and M. R. Begum. 2008. Determination of economic injury level of Helicoverpa armigera (Hubner) in chickpea. Bangladesh J. Agril. Res. 33(3) : 555 - 563. 


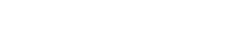

قيم الفلدفي محصط الذرة لقير مستوبل الضرر لإفتصاية نتيجة الإصلبة بالثلفبلتمع المكلفحة

\section{بالمبيدات تهت الاروف المصرية}

مجدى عبد الظاهر مسعود، عثمان لحمد زغلول، لحمد صبحى بركك، أحمدمحمد عبية،عمرو عبد الطيف البوجليل

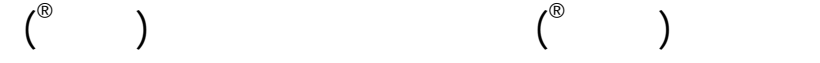
أزادارلختين (لأشوكك) والكونترول عى الترتيب.

وبقدير قيم مستوى الضرر الإقتصادى خلل الموسمين

لمشرات ثالقبات الذرة مجتمعة لظٔلمهرت النتائج القيم التالية

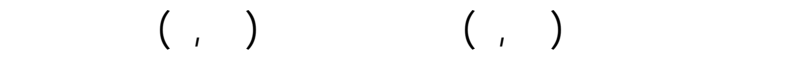

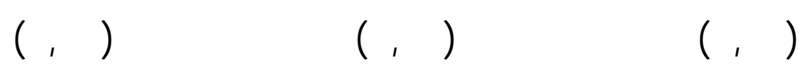

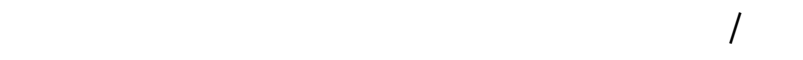

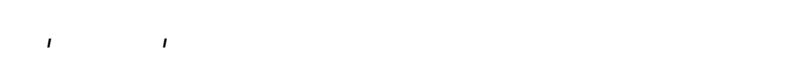

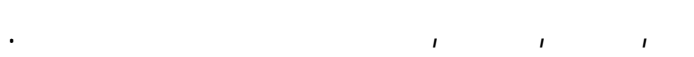
وبالنبة لدولة القصب الصغيرة كلت النتائج •7, · ل

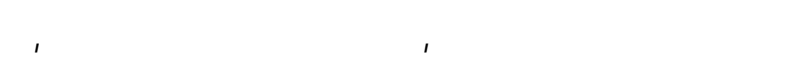

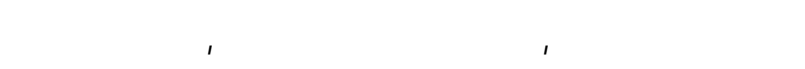

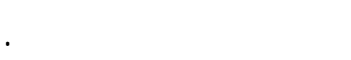

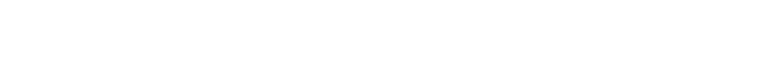
مستوى الضرر الاقتصادى التالية:

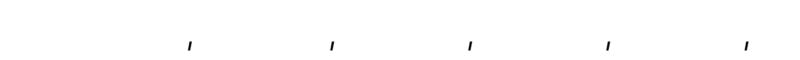

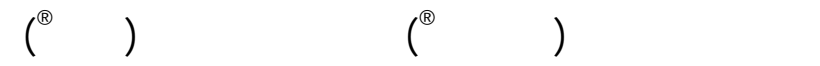

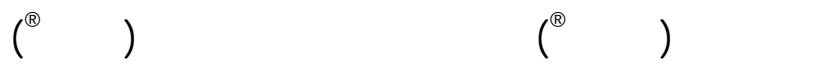

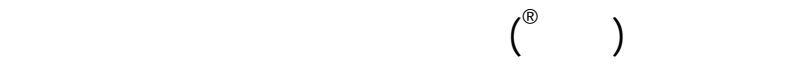

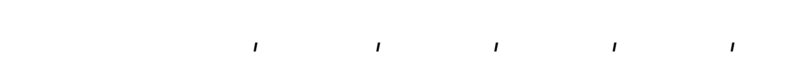

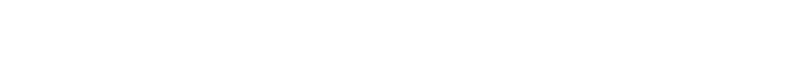

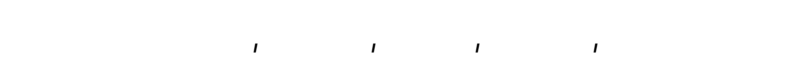
سالفة النكر على الترتيب.
يعتبر محصول الذرة ثالث أهم محاصلي الحبوب من نلحية الإقتصاد الزراعي بعد محصوله القمح والأرز على اله مستوى العالم حيث الهه مصدرا لغذاء الإنسان والحيوان وكذك مصدرا من مصادر التناج الزيت والكحول والنشا.

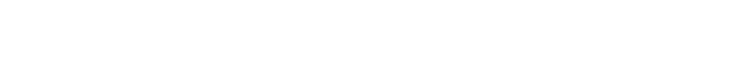
للإصابة بثاقبت الذرة وهى دودة القصب الكبيرة ودودة القصب الصغرى وحفارسلق الذرة الأوربي والتى تهفر دلخلسيقان النباتتا.

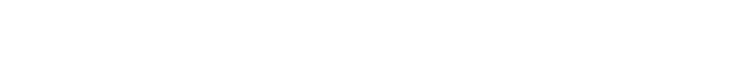

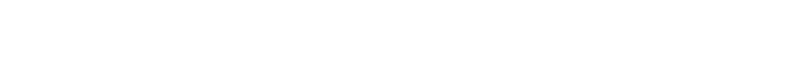
الذرة نتيجة للإصابة بالآثل الهثرية اللسابق نكرها بولنطة إستخدلم خمسة مبيدات وهي كلوروترانيانيليبرول

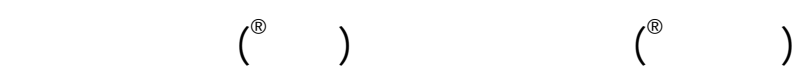

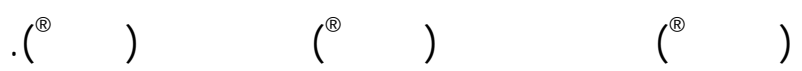

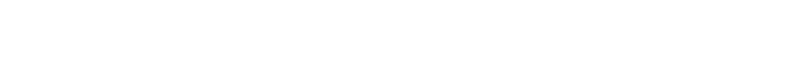
الحبوب كالتاله: - صفر، r

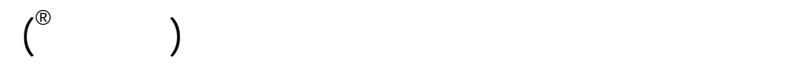

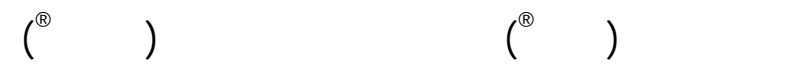

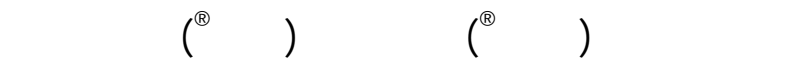

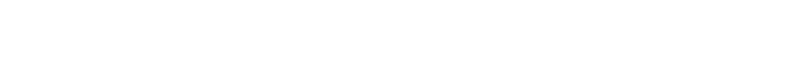

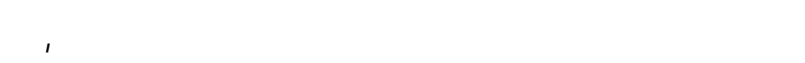
9,9v

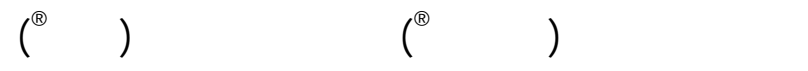

